\title{
Agriculture for All; Constraints to Youth Participation in Africa
}

\author{
Udemezue JC* \\ National Root Crops Research Institute, Nigeria \\ *Corresponding author: Udemezue Jc, National Root Crops Research Institute, Umudike, Nigeria
}

Received: 非July 12, 2019

Published: 笽 July 22, 2019

\begin{abstract}
Youths are the essential resources for every nation, especially for sustaining agricultural productivity as an important sector for nation building. Unfortunately, this category of people is virtually left out in policies and program considerations even though this is a critical stage for this group of people for transition into adulthood. The unemployment rate of this group globally ranked $12.6 \%$ compared with $4.8 \%$ as the rate of the adults in 2010 and this has the possibility of tempting most youth to embark on migration especially to urban centers and beyond since this act creates opportunities for accessing job opportunities. Agriculture being one of the foundation pillars of any society can only function as such if this insufficient youth participation is reversed. For instance, improving youth productivity in the agricultural sector and exploring effective livelihood diversification is imperative. Also, investing in the youth by promoting good habits is crucial if they are to realize their full potential. Involvement of youth in agricultural activities has the potential of reducing the problems of the ageing farm population and decreasing youth unemployment and this calls for securing the interest and participation of young people in agriculture in the form of a deliberate shift in policy, training and promotion that specially targets the youth.

This category of people is not only the productive backbone of every society, the major source of ideas and innovation, but also the main market for food consumption and very often the leaders and drivers of public opinion, public policy and action. As a result of this, this paper used already published literature to review the constraints to youths' participation in agriculture in Africa. However, the paper recommended that: Youth's organization example, young farmers clubs, should be encouraged and strengthened in some African states in order to obtain moral education and material assistance needed for agricultural transformation. There is the need for all well to do persons to support the youth in participating actively in agricultural production and to help them prevent those major factors that militates against their participation. Youth should be deeply involved in policy formulation; to this end, the youth should be encouraged to voice their constraints in relation to livelihood and also come together to form cooperatives for the purpose of sourcing loans for establishing farms. The image of agriculture as a dirty enterprise and a non-professional course as regarded by other professionals and laborious work with little returns must be changed, so that youth should be seeing agriculture as an inspirational career choice for African youth.
\end{abstract}

Keywords: Agriculture; constraints; youth's participation

\section{Introduction}

Agriculture remains fundamental to poverty reduction and economic growth in the 21st Century (World Bank, 2008). However, $75 \%$ of the world's poor are from rural areas and most are involved in farming, an activity which requires sustenance especially by the youth who are the leaders of tomorrow. Youth aged from 10 to 24 years old, $27 \%$ of the world's population and $33 \%$ of the population in Africa according to Nugent (2006). African agriculture is beset by a host of challenges such as lack of market access, low productivity on-adoption of modern farming systems, climate change, low fertilizer usage, and inadequate storage and processing facilities Francis et al. [1]. Africa has an exceptional population profile: 200 million people living in Africa are between the ages of 15 to 24, constituting over $20 \%$ of the African population; $70 \%$ of African youth reside in rural areas and account for $65 \%$ of the labor in agriculture. Young people make up $36 \%$ of the working population, and account for $60 \%$ of the total unemployed International Labor Organization ILO [2]. The large youth population in Africa should be seen as an asset for the continent's development if appropriate human capital investment measures are taken. Youth participation in agriculture is thus beneficial to mankind both directly and indirectly. It will provide under- and un-employed young people with employment and income, and this in turn will provide the food we need via increased production, and ensures farming is passed from one generation to the next. Indirectly, it will drastically reduce 
the criminal and illegal activities youth may indulge in due to lack of gainful employment.

Youth are very important resources for every nation, especially for sustaining agricultural productivity and an important sector for development Francis at al.[1]. Youth can be stakeholders in the development process, especially in view of the great assets of youth, resilience, resourcefulness and perseverance. Unfortunately, this category of people is virtually left out in policies and program considerations even though this is a critical stage for this group of people for transition into adulthood FAO [3]. For instance, the unemployment rate of this group globally ranked $12.6 \%$ compared with $4.8 \%$ as the rate for adults in 2010 and this has the potential of tempting most youth to embark on migration especially to urban centers and beyond since this act creates room for accessing job opportunities (United Nation (UN) (2011) in Francis et al. [1]. This group of people account for over 1.8 billion people in the world today, $90 \%$ of whom live in developing countries, where they tend to make up a large proportion of the population and need to be empowered since this is an important means of improving food security, youth livelihoods and employment. According to Mangal [4], there is insufficient youth participation in the agricultural sector even though this category of people is the most productive of any society as it contains people in the prime of their lives physically and mentally. Agriculture being one of the foundation pillars of any society can only function as such if this insufficient youth participation is reversed. For instance, improving youth productivity in the agricultural sector and exploring effective livelihood diversification is imperative. Also, investing in the youth by promoting good habits is crucial if they are to realize their full potential. This is in view of the fact that the number and proportion of the older persons is growing faster than any other age group UNFPA and HelpAge International [5].

In Africa, $20 \%$ of the population is aged between 15 and 24 years, comprising more than $20 \%$ of the population and a large majority lives in rural areas. Being $37 \%$ of the workingage population, rural youth who are attached to agriculture are disadvantaged and this is because consideration of the youth as future farmers in Africa has not received adequate attention. This category of people is the driving force behind economic prosperity in future decades, only if policies and programmes are in place to enhance their opportunities Ashford [6]. According to Dr Namanga Ngogi, President of Alliance for a Green Revolution in Africa (AGRA), $60 \%$ of Africa's population resides in rural areas and the large majority of this population is made up of youth. However, the poor participation of this group of young people in farming is a threat to the future of agriculture and rural economic transformation on the continent Ghana News Agency [7]. Therefore, for youth to be accommodating, agriculture should be subsidized in various forms to make it attractive to young farmers and the likes of students. There is no subsidy that agriculture cannot accommodate because every human being whether poor or rich eats food and every citizen is a stakeholder in agriculture. Everybody is a direct beneficiary of any kind of subsidy on agriculture. Therefore, whatever affects agriculture indirectly affects all directly. Agriculture is for all, because it had no class distinction, everybody regardless of social status eats food on a daily basis. It on this premise that this paper was 'incubated' and 'hatched' to probe the constraints militating against youths' participation in agriculture in African countries.

\section{Constraints to Youths' Participation in Agriculture}

Involvement of youth in agricultural activities has the potential of reducing the problems of the ageing farm population and decreasing youth unemployment and this calls for securing the interest and participation of young people in agriculture in the form of a deliberate shift in policy, training and promotion that specially targets the youth. This category of people is not only is the productive backbone of every society, the major source of ideas and innovation, but also the main market for food consumption and very often the leaders and drivers of public opinion, public policy and action Akpan [8]. In the light of the above Francis at al. [1]. however, saw the factors militating against this as multi-faceted and they can be grouped into two major sub-headings namely: Exogenous and Endogenous. Endogenous factors are factors that emanate from the youth themselves as being reasons for their non-engagement with Agriculture. These factors include.

\section{Disinterest}

Agriculture is not considered to be delivering the types of lifestyles and status that young people desire and expect. Agriculture is not considered able to deliver via incomes and working conditions the kinds of lifestyles young people need, expect and desire in the 21st century, lifestyles that are ever more visible thanks to revolutionary advances in communications technology that is accessible to (almost) all, even people living in the most remote rural areas. In this respect, agriculture is regarded as a poor person's activity, going beyond living standards to people's sense of pride and self-respect. These are important dimensions of wellbeing and take us beyond narrow, one-dimensional conceptions of what it means to be poor, marginalized and disadvantaged ILO [2]. If agriculture is not able to deliver either the desired living standards or the prospects for upward mobility, then the likelihood of attracting young people into or retaining them in the sector is low.

\section{Doubt}

youth do not have a strong conviction that agriculture can be a lifelong career choice able to provide their needs and wants. Thus, they stay aloof and un-involved even when they are well-poised by education or experience to make a living out of it. Most young people have no interest in agriculture, which is not within their own visions for their future. This is often echoed by their parents. By agriculture, people invariably think of farming as backbreaking work, low input, 365 days a year for little or low return.

\section{Negative Perception}

youths perceive agriculture negatively. As something you do if you fail in school, as migrants in town or abroad, or by the side with other non-farm businesses. Or it may not even be an option at all with pressure on resources, especially land scarcity, which pose serious barriers to entry for young people. An apparent sense of insecurity around farming, related to unpredictable climate 
variability, volatile food prices, rising costs, all this further acts as a deterrent. Exogenous factors refer to factors that are outside the control of the youth which affect their ability and capacity to engage with Agriculture. They include the following:
a. Dearth of infrastructure
b. Generalizing the youth demographic;
c. land tenure system;
d. finance/capital;
e. lack of information on agribusiness opportunities;
f. poor marketing and media relations;
g. ineffective career guidance;
h. exclusion of youth from policy-making processes;
i. disconnect between agricultural education and practice; and

j. absence of workable schemes/programmes.

\section{Dearth of Infrastructure}

Rural areas are notably more deficient in physical and social infrastructure than urban areas leading to rural-urban migration with the attendant removal of youth from the rural areas where agriculture is mostly practiced. Young people are aware of lifestyles in other regions within their countries and globally. As long as urban areas offer a more attractive destination for young people's desired lifestyles, more youth will continue to leave the rural areas. Availability of good roads, constant electricity, recreational facilities, internet, potable water, affordable housing and qualitative healthcare in rural areas will go a long way in retaining youth in rural areas and improving their engagement with agriculture.

\section{Generalizing the Youth Demographic}

One of the key obstacles to sustainable youths' engagement with agriculture is the generalization of the "youth" demographic by policymakers. Attitudes of young people towards agriculture vary extensively and some of the distinguishing factors are largely geographic location and land ownership. Even with campaigns to stimulate interest or raise awareness to the positive prospects of agriculture, there is a crucial need to segment the "youth" so the right message can be communicated to the right audience. The reality of the matter is that youth who have been exposed to agriculture, e.g. those from rural settings where subsistence farming is largely dominant, will probably understand the value of agriculture and its role as a key component of food security but might feel that it is not very progressive as most people in their communities might still be subsistence farmers who are struggling to not only carry their financial needs but also progress from subsistence farming to commercial farming. On the other hand, youth in urban settings might have little or no exposure to agriculture which requires a different marketing approach.

\section{Land Tenure and Access}

The land tenure system in most African countries makes access to land for agricultural purposes a herculean task. Agriculture is a land-based activity and youth are excluded from easy access to adequate and suitable land. This effectively dissuades them from engaging with the sector.

\section{Lack of Information on Agribusiness Opportunities}

A lot of young people struggle to access information on agriculture and agribusiness. They are not even aware of the enormous range of opportunities obtainable in the sector. Most perceive agriculture from the production side only. A massive emphasis needs to be invested in making information easily accessible in schools, libraries and local municipalities. There is also equal demand for the information to be in languages and grammar the youth understand and to span the full range of areas where youth can engage with agribusiness.

\section{Exclusion of youth from policy-making processes}

The youth need to be part of dialogues focusing on agricultural policies. If we acknowledge their vast population dynamics, surely, we need to include them in the formulation and implementation of policies affecting their future. In addition, whilst there is also a need to look into new policies that best reflect the current economic, social and political climate, equal focus needs to be invested in the implementation of these policies as in some instances many policies have not seen the light the day.

\section{Capital, Finance and Collateral}

Most young people do not have access to funding for agricultural purposes. They usually are not able to access finance from financial institutions because they do not possess collateral acceptable to banks and other financial institutions.

\section{Poor Marketing and Media Relations}

Another challenge is the poor promotion of agriculture. There is a need for more coverage in print and electronic media, radio and television, local and national stations. Programming needs to be shown during prime time, if expensive at least when young people are watching. There is a need to make programming that displays agriculture that looks cool and attractive to people. We also need testimonials of successful young farmers. The internet particularly social media can also be good tools to promote agriculture if used effectively. With the surge of internet access among the youth, institutions promoting agriculture need to acknowledge the youth's shift from traditional media especially newspapers. Nowadays, most young people get their information from the internet so the internet would be one of the best platforms to market and promote agriculture to reach the youth demographic.

\section{Ineffective Career Guidance}

The absence of effective career guidance in schools is one huge component that derails youth participation in Agriculture. The poor promotion of agriculture in schools as a tertiary study unit is another key component that adds to the poor interest. Therefore, institutions that promote agriculture need to hold career expos in rural and urban settings to promote agriculture as a study unit, they 
need to make electronic and print media available to the youth.

\section{Disconnect between Agricultural Education and Practice}

Higher education levels overall mean that young people are being educated on the agricultural systems in both local and global applications. With higher levels of education, they seek jobs with higher skill levels than those of the smallholder farming activities that are available locally. But higher unemployment levels, especially among the youth, suggest that work and education are failing as key routes by which people move out of poverty, and as crucial mechanisms linking economic growth to poverty reduction. More children than ever go to school, but what they learn appears to be far removed from the skills needed in the 21st Century. This is true for agriculture sector skills as any other. African agricultural graduates often lack practical skills and competences required for successful agro-preneurship. More so, the East Africa Farmers Federation (2009) observed that youth who aspire to farming as a livelihood face many obstacles - some common to all smallscale farmers, others particularly pertinent to their age group. In an East Africa regional youth consultative workshop held in Uganda (East Africa Farmers Federation, 2009) a number of issues were identified that make it difficult to attract young people into agriculture. Shortage of production resources such as land and finance; Negative attitudes about agriculture; Limited agricultural knowledge and skills as well as leadership and managerial skills; Limited youth groups and associations/cooperatives; Youth involvement in decision-making still low; Attraction of quick gains especially from white collar jobs; Lack of youth policies; Lack of support from elders for youth in agriculture; Lack of experience and skill sharing; Lack of market accessibility; Lack of supportive social services and infrastructure; Unwillingness of educated youth to engage in agriculture; and Absence of youth departments in national farmer federations.

Wong [9] identified the following as being the barriers to youth engagement in agriculture: Farmers' clubs lack coordination, harmonization and adequate funding for these initiatives was reported; Negative perceptions, limited access to production resources and lack of institutional support and incentives towards farming; Lack of political will, accountability and support mechanisms to youth concerns in the sector was noted; Many youth perceive farmers as uneducated, unskilled and as physical laborers who receive low returns from farming when compared to other formal and informal forms of employment; Institutional issues were also identified to include; lack of a sectoral youth policy, failure to include agriculture among the thematic areas in the National Youth policy, as well as lack of emphasis on agriculture in the current education system. There are also no role models in the sector and the majority of the out of school youth interested in agriculture face numerous constraints in relation to access and control over the resources needed to engage in viable agribusiness. In view of the above, the constraints militating against youths' participation in agriculture in Africa are as follows; inconsistent government policy and administration, underfunding of agricultural research institutes, embezzlement of agricultural funds by politicians and government officials, false representation of the agricultural image by other professionals, lack of maintenance of agricultural infrastructures, death of young farmers' clubs in some states in African countries, youths' perception and orientation on agriculture, lack of accommodating youths in policy formulation, poor marketing and communication channels, ineffective mentor on career guidance, lack of mechanization, individual attitude towards agriculture and death of some agricultural projects in Africa.

\section{Conclusion and Recommendations}

It is clear that sustainable youth engagement with agriculture will result in positive results not limited to food security. It will also have positive impacts on unemployment, economic development, rural-urban migration, peace and national security for African countries. However, to harness these potentials, government and stakeholders must think beyond conceiving youths as units of labor to be placed in jobs. Effective empowerment and engagement of young people in agriculture requires the ability of the sector to address youths' aspirations, expectations, the constraints and desire for social mobility. In view of this, this paper recommends that: An Empowerment program be institutionalized by an act so that necessary structures will be put in place and sustainability guaranteed. In this regard, community development experts should be involved so that some technical and structural challenges will be handled professionally and relevant desires for the youth attracted. Transparency and accountability should also be encouraged through adequate supervision, monitoring and evaluation to avoid embezzlement of the funds allocated to agricultural projects.

The image of agriculture as dirty, a non-professional course as regarded by other professionals and laborious work with little returns must be changed, so that youth should be seeing agriculture as an inspirational career choice for African youth. There is need for joint efforts among all the sector players towards enhancing youth participation in agriculture. These efforts include: the use of appropriate strategies to support creative and exciting agribusiness opportunities for the youth, attitude change and enhancing youths' access to resources, review of the National Youth Policy and its implementation strategy, to be followed by dissemination of these documents to all development partners. National level youth specific strategies need to be initiated to enhance youths' access to arable land and other inputs to support professional commercial farming. The success of such efforts will not only create employment opportunities for the youth, but also contribute highly towards changing agricultural production from its subsistence form to professional, agribusiness and value chain-oriented systems. There is the need for every well to do persons to support the youth in participating actively in agricultural production and to help them prevent those major factors that militates against their participation.

Youth should be deeply involved in policy formulation. To this end, the youth should be encouraged to voice their constraint to livelihood and also come together to form cooperatives for the purpose of sourcing loans for establishing farms. There is need for joint efforts among all the sector players towards enhancing youth participation in agriculture. These efforts include: the use of 
appropriate strategies to support creative and exciting agribusiness opportunities for the youth, attitude change and enhancing youths' access to resources, review of the National Youth Policy and its implementation strategy, to be followed by dissemination of these documents to all development partners.

National level youth specific strategies need to be initiated to enhance youths' access to arable land and other inputs to support professional commercial farming. The success of such efforts will not only create employment opportunities for the youth, but also contribute highly towards changing agricultural production from its subsistence form to professional, agribusiness and value chainoriented systems. Youth's organization for example, young farmers' clubs, should be encouraged and strengthened in some African states in order to obtain moral education and material assistance needed for agricultural transformation.

\section{References}

1. Francis A, William NM, Mathenge PM (2015) Youth Engagement in Agriculture in Kenya: Challenges and Prospects. Journal of Culture Society and Development 7(4)
2. International Labor Organization (ILO) (2012) Global employment outlook September 2012: Bleak Labor Market Prospects.

3. FAO (2009) The state of food and agriculture: Livestock in the balance. Food and agricultural organization of the United Nations Rome 2009 for Youth Rome: ILO.

4. Mangal H (2009) Best practices for youth in agriculture: The Barbados, Grenada and Saint Lucia Experience. Final report.

5. UNFPA and HelpAge International (2012) Ageing in the twentyfirst Century: A celebration and a challenge. UNFPA and HelpAge International: New York, USA.

6. Ashford LS (2007) Africa's youthful population: Risk or opportunity? Population Reference Bureau: Washington DC USA.

7. Ghana News Agency (2012) Making agriculture attractive to the youth.

8. Akpan SB (2010) Encouraging youth's involvement in agricultural production and processing. International Food Policy Research Institute: Nigeria.

9. Wong I (2009) Increasing youth involvement and engagement.

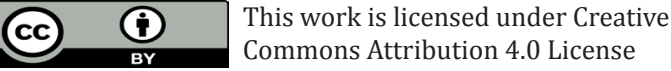

To Submit Your Article Click Here: Submit Article

DOI: 10.32474/CIACR.2019.07.000256

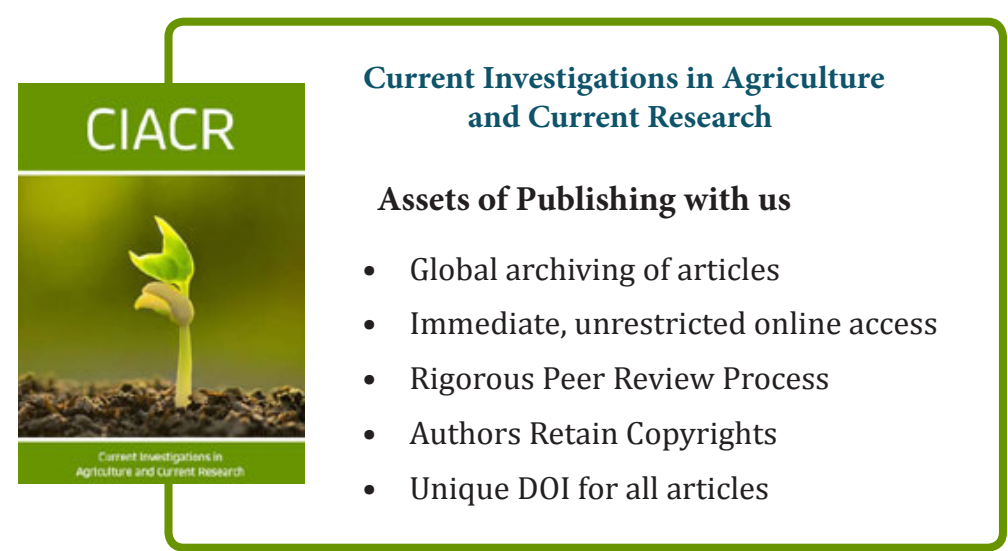

